\title{
Resiliensi Pesantren Terhadap Ekstrimisme Kekerasan Berbasiskan Agama dan Implikasinya terhadap Masyarakat Pesisir Lamongan
}

\author{
${ }^{1}$ Nafik Muthohirin; ${ }^{2}$ Suherman \\ $1 \& 2$ Universitas Muhammadiyah Malang, Indonesia \\ 1nafikmuthohirin@umm.ac.id; 2suherman@umm.ac.id
}

\begin{abstract}
Pesantren has a strategy of resilience from the infiltration of the ideology of religious violent extremism. This resilience comes from the kiai's charisma and institutional commitment to the integrity of the country which has implications for the practice of Islamic education in Islamic boarding schools. This article discusses the form of the resilience of the Pesantren Karangasem Muhammadiyah Lamongan from the ideology of religious violent extremism. Pesantren Karangasem is located in Paciran, which borders Brondong, Lamongan, where religious life in the two coastal villages of Lamongan faces serious challenges because it is becoming pockets of movement for Islamic extremist groups. This article poses two thesis questions: First, what is the form of the resilience of the Pesantren Karangasem from the ideology of religious violent extremism; Second, how this form of resilience can have implications for preventing the entry of radical Islamic actors into the religious life of the coastal community of Lamongan. This study concludes that Pesantren Karangasem is an Islamic educational institution that contributes to spreading moderate Islamic views through several forms of resilience that originate from the kiai's charisma and the Islamic intellectual tradition of the pesantren. This study also emphasizes that even though the infiltration of massive religious-based violent extremism movements has occurred, the practice of Islamic cosmopolitan which is the character of religious life in the coastal community of Lamongan is always maintained.
\end{abstract}

Keywords. Violent extremism; Pesantren; Resilience; Kiai; Moderate Islam

\begin{abstract}
Abstrak. Pesantren memiliki strategi ketahanan dari infiltrasi ideologi ekstremisme kekerasan agama. Ketahanan tersebut bersumber dari karisma kiai dan komitmen institusi terhadap keutuhan negara yang berimplikasi pada praktik pendidikan Islam di pesantren. Artikel ini membahas bentuk ketahanan Pesantren Karangasem Muhammadiyah Lamongan dari ideologi ekstremisme kekerasan agama. Pesantren Karangasem terletak di Paciran yang berbatasan dengan Brondong, Lamongan, yang kehidupan beragama di kedua desa pesisir Lamongan tersebut menghadapi tantangan serius karena sedang menjadi kantong pergerakan kelompok ekstremis Islam. Artikel ini mengajukan dua tesis pertanyaan: Pertama, bagaimana bentuk ketahanan Pesantren Karangasem dari ideologi ekstremisme kekerasan agama; Kedua, bagaimana bentuk ketahanan tersebut dapat berimplikasi mencegah masuknya aktor-aktor Islam radikal di kehidupan beragama masyarakat pesisir Lamongan. Penelitian ini menyimpulkan bahwa Pesantren Karangasem merupakan lembaga pendidikan Islam yang berkontribusi menyebarkan pandangan Islam moderat melalui sejumlah bentuk resiliensi yang bersumber dari karisma kiai dan tradisi intelektual Islam pesantren. Kajian ini juga menegaskan, meski infiltrasi gerakan ekstrimisme kekerasan berbasiskan agama masif terjadi, namun praktik kosmopolitansime Islam yang menjadi watak kehidupan beragama masyarakat pesisir Lamongan senantiasa terjaga.
\end{abstract}

Kata Kunci. Ekstrimisme Kekerasan; Pesantren; Resiliensi; Kiai; Islam Moderat.

Copyright (C J-PAI: Jurnal Pendidikan Agama Islam. All Right Reserved.

This is an open-access article under the CC BY-SA license

(https://creativecommons.org/licenses/by-sa/4.0/).

Correspondence Address: jpai@uin-malang.ac.id 


\section{A. PENDAHULUAN}

Pasca kelompok teroris internasional Al-Qaidah melakukan serangan terhadap World Trade Center (WTC) dan Pentagon di AS (2001), kemudian disusul Bom Bali I di Indonesia (2002), kemudian disusul berbagai aksi terorisme pada satu dekade ke belakang, misalnya bim bunuh diri satu keluarga yang menyerang Gereja Santa Maria Tak Bercela, Gereja Pantekosta dan GKI Diponegoro di Surabaya (2018) dan bom bunuh diri di Gereja Katedral di Makassar (2021), studi akademis yang mengaitkan antara Islam dengan terorisme menjadi sangat berlimpah.

Melalui banyak kajian akademis tersebut, tidak sedikit sarjana yang mendeskripsikan Islam sebagai agama berwajah teror (Lewis, 2002). Namun, tidak sedikit yang mengkajinya melalui pendekatan pencegahan. Salah satu model deradikalisasi ideologi terorisme dapat dilakukan melalui pendidikan Islam, yang dalam hal ini diwakili oleh keberadaan pesantren dan madrasah.

Pesantren atau madrasah menjadi praktik baik dalam pencegahan ideologi Islam radikal. Lembaga pendidikan Islam ini mewariskan berbagai sikap keterbukaan dan penghargaan terhadap keberagaman (Marzuki et al., 2020). Pesantren juga memiliki resiliensi terhadap doktrin Islam radikal yang didasarkan pada kohesi sosial melalui karisma seorang kiai dan model pendidikan keagamaan yang modern dan berkemajuan. Irfan Abubakar dan Idris Hemay menjelaskan, resiliensi pesantren berlangsung melalui sistem internal yang membentuk kohesi sosial, yang lalu membangun identitas sosialnya sendiri. Kohesi sosial itulah yang membentengi komunitas pesantren dari identitas baru yang datang belakangan, yang dalam hal ini berwujud aktor-aktor Islam radikal (Abubakar \& Hemay, 2020).

Sebab itu, tidak sedikit peneliti yang menjadikan pesantren atau madrasah sebagai obyek kajian dalam menumbuhkan nilai-nilai perdamaian, demokrasi, multikultural, sikap moderat dan resiliensi terhadap ancaman ideologi ekstrimisme kekerasan berbasiskan agama. Kathleen E. Woodward mengapresiasi proses berlangsungnya pendidikan Islam di Indonesia. Dia mengamati penerimaan masyarakat Indonesia yang mayoritas Muslim terhadap demokrasi dan sistem politik negara bangsa (nation-state) sangat dipengaruhi proses pengajaran Islam di berbagai lembaga pendidikan Islam. Menurutnya, doktrin agama di sekolah Islam (maupun negeri) tidak diajarkan secara kaku. Peserta didik diajak berijtihad dan berfikir kritis mengontekstualisasikan pemahaman Islam dengan semangat kemajuan zaman (Woodward, 2015).

Farish A. Noor, Yoginder Sikand, dan Martin van Bruinessen (2008) menolak tesis yang menyebut pesantren sebagai tempat pencetak teroris sebagaimana yang sering disuarakan media internasional. Argumentasi tersebut tidak beralasan karena jikapun ada milisi yang berpendidikan pesantren, hal itu tidak ada hubungannya dengan sistem pembelajaran atau kurikulum pendidikan Islam yang berlangsung di lembaga pendidikan Islam tersebut (Farish A. Noor, Yoginder Sikand, 2008). Proses radikalisasi dipengaruhi oleh beragam faktor, yang salah satunya berasal dari anggapan bahwa negara-negara Muslim sedang mengalami kemunduran dan ketidakadilan sosial-ekonomi sebagai akibat dari kemajuan Barat. Doktrin provokatif inilah paling dominan dijadikan sebagai doktrin radikalisasi kelompok ekstrimis (Tibi, 1998).

\section{B. METODE}

Penelitian ini menggunakan metode riset kualitatif-deskriptif yang didasarkan pada tinjauan literatur dari jurnal, buku, dan artikel yang berkenaan dengan topik dari judul riset ini. Metode kualitatif sengaja dipilih karena ingin memberikan penekanan pada tiga hal penting, yaitu proses, ketajaman analisis dan pemaknaan hasil penelitian. Tiga hal tersebut merupakan kekuatan dari sebuah penelitian yang menggunakan metode kualitatif. 
Untuk melengkapi tiga kekuatan itu, riset kualitatif ini juga disertai penggalian data berdasarkan pengamatan langsung dan wawancara mendalam. Pengamatan dilakukan melalui dua cara, yaitu luar jaringan (luring) dan dalam jaringan (daring). Untuk observasi dengan cara luring, peneliti terlibat dalam berbagai aktifitas keislaman santri di Pondok Pesantren Muhammadiyah Karangasem Lamongan. Sementara observasi daring, penulis mengamatinya melalui berbagai unggahan video ceramah kyai atau ustadz dan program kegiatan pesantren di akun YouTube official Pesantren.

Melalui model pengamatan luring dan daring tersebut memungkinkan peneliti untuk mengetahui berbagai aktifitas resiliensi Pesantren Karangasem terhadap ideologi gerakan ekstrimisme kekerasan berbasiskan agama. Dalam hal ini, pengamatan luring juga memberikan kesempatan peneliti untuk mewawancarai sejumlah pihak yang memiliki hubungan bagi pengembangan naskah penelitian ini.

\section{HASIL DAN PEMBAHASAN}

Lamongan disebut sebagai salah satu kabupaten di Indonesia yang menjadi penyumbang "jihadis" terbanyak ke Suriah. Terdapat 16 warga di pesisir utara Jawa Timur tersebut yang bergabung dengan ISIS (Islamic State of Iraq and Suriah) pimpinan Abu Bakar al-Baghdadi pada 2017. Institute for Policy Analysis of Conflict (IPAC) menyebut jaringan kelompok Islam radikal di Lamongan telah bertransformasi menjadi sentimen pro ISIS (Indonesia's Lamongan Network: How East Java, Poso, and Syria are Linked, 2015). Daerah yang makmur dengan hasil pertanian dan perikanan itu telah menjadi kantong perekrutan kelompok ekstrimis Islam.

Siswanto adalah figur utama di balik masifnya gerakan dan diseminasi pemikiran ekstrimisme Islam di pesisir Lamongan. Pria yang pernah mengenyam pendidikan di Pondok Pesantren Ngruki Solo tersebut pernah menjadi anggota Jamaah Islamiyah (19931994) dan pernah mengikuti panggilan Jihad ke Poso di sekitar tahun 2000-an. Ketika berjihad di Poso, dia menjalin hubungan baik dengan pendiri Jamaah Ansharut Daulah (JAD) Aman Abdurrahman. Siswanto menjadi pengikut setia Aman dan sering mengundangnya menjadi penceramah dalam pengajian Islam yang diselenggarakan Front Pembela Islam (FPI) Lamongan (Indonesia's Lamongan Network: How East Java, Poso, and Syria are Linked, 2015).

Menurut mantan Wakil Sekretaris FPI Lamongan Hendrik Irawan, benih ekstrimisme Islam mulai tumbuh di Lamongan sejak saat itu. Berbagai aksi persekusi dan kekerasan yang mengatasnamakan amar ma'ruf nahi munkar berpusat di dua kecamatan, yaitu Brondong dan Paciran. Selain menjadi kantong perekrutan kelompok Islam radikal, kedua kecamatan itu juga menjadi tempat berseminya berbagai organisasi Islam fundamentalis (Tibi, 1998). Di antara sejumlah kelompok Islam fundamentalis yang tumbuh di dua kawasan tersebut, yaitu Hizbut Tahrir Indonesia (HTI), Jamaah Salafi, dan Harakah Tarbiyah. Keberadaan mereka dapat dibuktikan melalui pendirian organisasi HTI, dan keberadaan sejumlah forum halaqah di masjid atau pengajian keislaman di rumahrumah warga setempat. Kemudian, menurut Zumrotin, keberadaan Pondok Pesantren AlIkhlas Sedayu Lawas, Brondong, Lamongan menjadi wujud eksistensi keberadaan kelompok Islam fundamentalis. Ideologi pesantren yang didirikan oleh KH. Abu Azzam Azhari Dipo Kusumo tersebut lebih dekat kepada Salafi Jihadi.

Kehadiran berbagai kelompok Islam berwatak salafi ideologis, politis dan jihadis tersebut membentuk sikap keberagamaan masyarakat pesisir Lamongan. Masyarakat muslim pesisir yang pada awalnya dikenal kosmopolitan menjadi ekslusif dan literatif. Isa Anshori menilai kenyataan tersebut dipengaruhi oleh terjadinya fragmentasi otoritas keagamaan yang sebelumnya didominasi Muhammadiyah dan Nahdlatul Ulama (NU), lalu 
dengan kemunculan sejumlah kelompok Islam fundamentalis tersebut, otoritas keagamaan menjadi terbelah (Anshori, 2020).

Meski keberadaan mereka tidak dominan, namun pemberitaan media yang sangat luas seperti ketika terjadi Bom Bali I (2002) atau laporan riset yang diproduksi IPAC (2015) yang menemukan jaringan Siswanto berafiliasi dengan ISIS, menjadikan pandangan umum bahwa daerah pesisir Lamongan kental dengan ideologi Islam radikal. Artikel ini berusaha untuk melakukan counter narasi dengan mengungkapkan corak kosmopolitanisme beragama masyarakat Muslim pesisir Lamongan, terutama dengan menghadirkan peran penting Pondok Pesantren Karangasem Muhammadiyah Lamongan dan Kyai Abdurrahman Syamsuri sebagai resiliensi dari ideologi ekstrimisme kekerasan berbasiskan agama.

\section{Sosial Keagamaan Masyarakat Pesisir}

Pesisir utara Lamongan terdiri dari 17 desa, yang mayoritas warganya sangat bergantung pada sektor perikanan hasil laut. Sebab itu, sebagian besar penduduknya bekerja sebagai nelayan dan pekerja kasar di Tempat Pelelangan Ikan (TPI). TPI Brondong dikenal sebagai TPI terbesar di Jawa Timur, dengan kemampuan menghasilkan ikan lebih dari 300 ton per hari. Pendapatan harian yang cukup besar dari hasil melaut dan mengangkut ikan di TPI membuat warga pesisir lebih konsumtif dibanding masyarakat petani. Mereka tidak terlalu mengerti pentingnya perencanaan atau pengelolaan keuangan secara mandiri.

Secara sosiologis, watak masyarakat pesisir Lamongan merupakan komunitas sosial yang egaliter dan terbuka. Mereka suka berkelompok, tidak individual, serta mudah diajak kerjasama. Berbeda dengan masyarakat di pedalaman, penduduk pesisir Lamongan tidak mengenal kasta sosial. Profesi tertentu seperti kiai kampung, mubaligh, modin (penghulu agama) dianggap tokoh karismatik yang menempati posisi penting di tengah masyarakat. Mereka menjadi rujukan warga untuk meminta nasihat agama dan memilih pemimpin. Meski kaum mudanya tidak banyak yang pergi ke masjid untuk sholat berjamaah atau mengaji al-Qur'an, namun masyarakat setempat masih menganggap masjid sebagai jantung kehidupan beragama secara umum.

Masyarakat muslim pesisir Lamongan memiliki sejumlah modal sosial yang menjadi faktor penguat persemaian berbagai organisasi keislaman. Di antara modal sosial tersebut yaitu sikap terbuka, egaliter, dan akomodatif yang telah mentradisi sejak lama. Nur Syam menyebut, corak Islam masyarakat pesisir Jawa sangat kosmopolitan. Proses kedatangan, penyebaran dan pelembagaan Islam di tanah Jawa merupakan fakta yang tidak dapat dibantah mengenai gambaran wajah kemajuan dan kemodernan Islam masyarakat pesisir Jawa (Syam, 2003).

Pada 1950-an, Masyumi pernah tumbuh besar di daerah ini (Faris Ma'ani, Bambang Siswoyo, 2012), diteruskan Muhammadiyah dan Nahdlatul Ulama (NU) melalui berdirinya banyak lembaga pendidikan Islam yang terafiliasi dengan keduanya (Anshori, 2020). Abdul Munir Mulkhan, dalam artikel Mu'arif di Suara Muhammadiyah yang berjudul Kosmopolitanisme Islam dari Pesisir menjelaskan, sesungguhnya masyarakat Muslim di sekitaran pesisir Jawa lebih dekat dengan Muhammadiyah. Muslim pesisir lebih moderat, meskipun lebih berorientasi pada fikih.

Ketika para pedagang Tiongkok masuk Jawa melalui jalur maritim yang sekaligus membawa misi Islam pada abad ke-13, watak kosmopolitan itu terbentuk sebagai hasil dari perjumpaan masyarakat lokal dengan mereka yang secara budaya memiliki perbedaan. Interaksi sosial tersebut memunculkan akulturasi budaya di banyak sektor, mulai bidang sosial, ekonomi hingga pada praktik beragama. Pada akhirnya, proses akluturasi ini 
Nafik Muthohirin, dkk.: Resiliensi Pesantren Terhadap Ekstrimisme Kekerasan ...

membentuk paradigma dialog yang transformatif di antara masyarakat lokal Jawa dengan para saudagar.

Di era kekinian, corak keislaman yang kosmopolitan pada masyarakat Muslim pesisir Lamongan tersebut mengalami tantangan serius karena berhadapan dengan kemunculan berbagai kelompok Islam fundamentalis, bahkan dianggap menjadi kantong perekrutan organisasi Islam ekstrimis. Tetapi, di sisi yang lain, Muslim pesisir Lamongan memiliki peluang besar untuk kembali membuktikan sebagai daerah yang penuh kedamaian, masyarakatnya hidup rukun dan saling toleran. Salah satu potensi yang bisa mendongkrak kembali wajah kosmopolitanisme Islam masyarakat pesisir Lamongan adalah dengan menampilkan peran penting moderasi Islam dari sektor pendidikan Islam pesantren.

Isa Anshori menyebut masyarakat Paciran merupakan daerah santri. Hampir di setiap desa di kecamatan tersebut berdiri pesantren, dan setiap pesantren memiliki kiai yang karismatik. Pondok Pesantren Karangasem Paciran Lamongan adalah salah satu lembaga pendidikan Islam yang berafiliasi dengan Muhammadiyah yang bisa menjadi teladan dalam meresonansikan sikap beragama masyarakat yang moderat dan kosmopolitan. Kemudian, melalui kapasitas keilmuan agama yang diakui, kekuatan kepemimpinan, dan pergaulan lintas organisasi keislaman yang diperankan pendirinya $\mathrm{KH}$. Abdurrahman Syamsuri, semua keteladanan ini bisa menjadi ikatan (bounding) yang kuat untuk merajut strategi resiliensi dari ideologi ekstrimisme kekerasan berbasiskan agama.

\section{Model Resiliensi Pesantren}

Dalam menghadapi arus besar konservatisme keagamaan, pesantren modern yang berafiliasi dengan Muhammadiyah memiliki model resiliensinya sendiri. Secara umum, kemampuan resiliensi itu berbasiskan pada komitmen Muhammadiyah terhadap pemerintah. Pada Muktamar Muhammadiyah ke-47 di Makassar (2015), Muhammadiyah menawarkan gagasan Negara Pancasila Darul Ahdi wa Syahadah (negara perjanjian dan persaksian). Hasnan Bachtiar menyatakan konsep ini merupakan strategi untuk membentengi warga Muhammadiyah dari berbagai ideologi yang merusak, seperti halnya persoalan radikalisme, konservatisme dan terorisme agama. Rumusan ini juga menjadi temali yang menguatkan relasi Muhammadiyah dengan pemerintah (Bachtiar, 2020). Konsep tersebut tidak hanya sebagai sebuah konsensus atas dukungan Muhammadiyah terhadap NKRI, tetapi juga sebagai sikap mengambil peran dalam mengisi agenda pembangunan bangsa.

Model resiliensi pesantren Muhammadiyah berpusat pada dua hal: Pertama, berbagai materi pelajaran yang diorientasikan kepada sikap cinta tanah air. Pemahaman nasionalisme ini senantiasa ditumbuhkembangkan kepada seluruh santri atau peserta didik melalui keteladanan dari seluruh stakeholder pesantren, proses belajar mengajar di kelas dan lewat sejumlah kegiatan ekstrakurikuler seperti keikutsertaan santri dalam gerakan kepanduan Hizbul Wathan (HW) dan Ikatan Pelajar Muhammadiyah (IPM). Kedua organisasi otonom Muhammadiyah tersebut mengajarkan anak-anak muda untuk menjadi manusia yang kosmopolitan, yaitu menghargai perbedaan, cinta perdamaian, serta menghidupkan nilai toleransi, kejujuran, keadilan, persatuan, dan kasih sayang untuk semua makhluk. HW dan IPM juga berkomitmen mendukung dan menaati Pancasila sebagai ideologi negara, demokrasi sebagai sistem pemerintahan, serta menjunjung nilainilai universal hak asasi manusia (HAM).

Kedua, resiliensi pesantren Muhammadiyah juga terjadi karena kiai menjadi patron figur yang karismatik yang patut diteladani. Sosok kiai pesantren dianggap berkarisma karena bisa berbahasa Arab, menguasai nahwu-sharaf, hafal al-Qur'an 30 juz, serta mengajarkan kitab-kitab Islam klasik. Intinya sosok kiai pesantren adalah panutan karena 
menguasi ilmu-ilmu keislaman dan mendakwahkannya kepada masyarakat secara luas. Selain itu, resiliensi pesantren tumbuh dan berakar kuat karena peran kiai dan alumninya yang mampu menjadi referensi beragama bagi masyarakat. Ribuan alumni pesantren Muhammadiyah menjadi guru agama dan mubaligh yang berperan besar dalam membangun sikap dan pemahaman agama yang moderat di tengah masyarakat.

Kedua model resiliensi tersebut tidak dijumpai pada berbagai pesantren yang berideologi salafi jihadis. Meski mereka memiliki figur kiai berpemahaman ilmu agama yang luas, tetapi karena tidak membuka diri pada pemahaman baru di luar doktrin kaku yang diyakininya, maka sikap tertutup itulah yang menjadi pintu masuk bagi aktor-aktor Islam radikal.

Bagan 1: Model Resiliensi Pesantren Muhammadiyah

\section{Orientasi Mata Pelajaran}

Materi pelajaran agama dan umum
memberikan porsi yang lebih terhadap pemahaman kewarganegaraan, nasionalisme, cinta tanah air, penghargaan terhada[ Pancasila, pengenalan terhadap pahlawan-pahlawan nasional, serta pendidikan agama yang berparadigma inkulusif dan moderat

$\begin{array}{lrr}\text { Orientasi } & \text { kegiatan } & \text { ekstrakurikuler } \\ \text { diarahkan } & \text { kepada } & \text { pembangunan }\end{array}$
nasionalisme dan pembentukan karakter peserta didik. Di antara nilai pendidikan karakter yang biasa diajarkan di IPM atau HW yaitu nilai kejujuran, keadilan, toleransi, gotong royong, mengakui perbedaan, serta mengedepankan dialog dalam menyelesaikan persoalan konflik.

\section{Kharisma Kiai}

Penguasaan terhadap ilmu-ilmu keislaman, terutama karena menguasai kitab-kitab Islam karya ulama klasik yang pemikriannya otoritatif dalam moderasi keislaman. Selain itu, karena hafal alQur'an 30 juz dan memahami artinya.

Kiai sebagai panutan masyarakat, karena berperan besar sebagai mubaligh, guru agama, imam, dan rujukan konsultasi berbagai hal oleh warga sekitar. Selain itu, kiai memiliki santri dalam jumlah besar, yang ketika lulus sebagian mereka menjadi kiai kampung yang mendiseminasikan pandangan keislaman yang moderat.

Pesantren Karangasem Muhammadiyah Paciran Lamongan yang didirikan KH. Abdurrahman Syamsuri pada 18 Oktober 1948 adalah prototip lembaga pendidikan Islam yang memiliki kedua model resiliensi tersebut, yaitu: Pertama, sebagaimana umumnya lembaga pendidikan Islam yang berada di bawah naungan Muhammadiyah, praktik pendidikan Islam di Pesantren Karangasem diselaraskan dengan filsafat pendidikan Muhammadiyah, di antaranya denganmengedepankan inklusivitas, rasionalitas, pluralitas dan penguasaan teknologi informasi. Kurikulum pendidikan Islam di Pesantren Karangasem relevan dengan ideologi Pancasila; Kedua, Pesantren Karangasem dipimpin oleh kiai yang karismatik. KH. Abdurrahman Syamsuri merupakan ulama lokal yang memiliki pengaruh luas dalam kehidupan sosial keagamaan masyarakat Jawa Timur. Demikian juga ketika pesantren ini dipimpin oleh KH. Abdul Hakam Mubarok, masyarakat pesisir Lamongan senantiasa menjadikan pandangan-pandangan keislamannya sebagai rujukan praktik beragama yang inklusif.

Keduanya adalah kiai pesantren yang juga berperan sebagai pengasuh, mubaligh, guru, pemimpin Muhamamdiyah, dan teladanbagi masyarakat Lamongan. Sebab itu, tidak mengherankan apabilakewibawaan figur kiai menjadi nafas kehidupan Pesantren Karangasem. Karisma inilah yang menjadi salah satu modal sosial yang memengaruhi tingkat kepercayaan masyarakat daerah sekitar untuk menitipkan anak-anaknya bersekolah di Pesantren Karangasem. Lebih dari itu, modal sosial tersebut mampu 
Nafik Muthohirin, dkk.: Resiliensi Pesantren Terhadap Ekstrimisme Kekerasan ...

membentengi lingkungan pesantren (termasuk desa-desa yang berada di sekitar pesantren) dari infiltrasi ide dan gerakan ekstrimisme kekerasan berbasiskan agama.

Sebagaimana umumnya lembaga pendidikan Islam yang berafiliasi dengan Muhammadiyah, Pesantren Karangasem menerapkan konsep pendidikan Islam yang berkemajuan. Pesantren yang terletak di pesisir Lamongan itu memiliki visi, misi dan praktik kurikulum pendidikan Islam yang selaras dengan filsafat pendidikan Muhammadiyah. Pesantren ini bervisi mewujudkan insan kamil dengankeseimbangan spiritual, intelektual, dan moral. Sementara misinya ingin menjadikan kehidupan bermasyarakat yang penuh kedamaian dan ketentraman. Visi dan misi ini sama sekali tidak bertentangan dengan komitmen Muhammadiyah terhadap negara,justru merupakan turunan dari konsep-konsep kunci filsafat pendidikan Muhammadiyah.

Praktik pendidikan Islam di Pesantren Karangasem juga tidak berlawanan dengan kurikulum pendidikan nasional. Perangkat pendidikan pesantren tersebut merupakan implementasi atas sikap keterbukaan pemikiran. Pengajaran dan pembelajaran ilmu-ilmu keislaman terimplementasi melalui pendekatan integrasi, sebuah metode pendidikan yang memadukan ilmu-ilmu keislaman dengan ilmu pengetahuan umum (sekuler).

Salah satu lembaga pendidikan yang berada di bawah naungan Pesantren Karangasem, yaitu MTS Muhamamdiyah 2 menjalin kerjasama dengan Cambridge Assessment Education, Cambridge University dengan membuka kelas internasional bertajuk "Information Technology Class Program (ITCP)". Proses pengajaran dan pembelajaran dalam program tersebut menggunakan Bahasa Inggris. Program ini juga memberlakukan kurikulum hasil perpaduan antara kurikulum nasional dengan kurikulum Cambridge University. Para santri atau peserta didik yang termasuk dalam program ini diharuskan bertempat tinggal di pesantren dan berkewajiban menghafal al-Qur'an minimal dua juz, serta mengikuti berbagai kegiatan keislaman lainnya.

Program ITCP merupakan intrepretasi dari para pimpinan Pesantren Karangasem atas pesan pemikiran KHA. Dahlan yang berharap supaya pendidikan di Muhammadiyah didorong untuk melahirkan "kiai-kiai berkemajuan" (Rosyidi, 1975). Dalam pemahaman yang kontekstual, praktik baik melahirkan kiai-kiai berkemajuan itu dilakukan dengan merealisasikan tiga program unggulan: (1) hafalan al-Qur'an; (2) penguasaan bahasa asing (Arab dan Inggris); (3) dan pencapaian prestasi akademik. Melalui ketiga program tersebut, Pesantren Karangasem Paciran akan bisa mencetak para mubaligh, hafidz, kiai dan ilmuwan yang mampu berkiprah hingga ke tingkat global, serta tetap berkomitmen membela dan memajukan agama, bangsa dan negara.

Pesantren Karangasem yang memiliki sekitar 2.750 santri dan 650 karyawan mencirikan diri sebagai lembaga pendidikan Islam yang terdepan dalam membentuk generasi al-Qur'an berwawasan global. Setiap santri yang berada di kelas Madrasah Tsanawiyah (Mts) dan Madrasah Aliyah (MA) diwajibkan memiliki hafalan al-Qur'an minimal dua juz hingga lima juz. Sementara santri yang duduk di kelas Sekolah Menengah Pertama (SMP) dan Sekolah Menengah Atas (SMA) tidak menjadi kewajiban, namun didorong untuk tetap memiliki hafalan. Dalam rangka memotivasi para santri untuk tekun menjaga hafalan, berbagai program khusus yang menunjang peningkatan hafalan diadakan, seperti Daurah Tahifdz dan kerjasama internasional dengan Persatuan Institusi Tahfidzul Qur'an se-Selangor, Malaysia, keterampilan senikaligrafi al-Qur'an, dan perlombaan Khattil al-Qur'an.

Selain itu, para santri juga diajarkansejumlah kitab hadist, tafsir dan akidah. Dua kitab hadistyang populer digunakan di banyak pesantren Muhammadiyah, yaitu Bulughul Maram dan Riyadhus Sholihin. Kitab yang pertama ditulis oleh Imam Ibn Hajar al-Astqalani dan yang kedua merupakan karya Imam Abu Zakariya Yahya bin Syaraf an-Nawawy. Keduanya termasuk dalam jajaran ulama besar pada abad ke tujuh dan delapan hijriah. 
Kitab lain yang juga diajarkan di kelas-kelas diniyah sore, yaitu Ta'limul Muta'alim, Minhajul Muslim, dan Bidayatul Mujtahidwa Nihayat al-Muqtasid. Kitab yang disebut terakhir merupakan karya filosof Muslim abad pertengahan, Ibnu Rusyd. Kitab Bidayatul Mujtahid mengajarkan tentang ragam pendapat para ulama dalam permasalahan fikih.

Pembelajaran kitab-kitab Islam klasik di Pesantren Karangasem sudah menjadi bagian integral dalam tradisiintelektualisme pesantren di Indonesia. Pengajaran kitabkitab Islam klasik ini berlangsung sama lamanya dengan sejarah berdirinya Pesantren Karangasem. Sejak berdiri pada 1948 hingga 1997, pengajaran kitab-kitab Islam klasik langsung dimbimbing Kiai Abdurrahman Syamsuri. Metode pembelajaran dilakukan melalui sorogan dan bandongan (Chirzin, 1995). Namun, pasca Kiai Abdurrahman meninggal, pengajaran kitab-kitab Islam klasik tersebut diteruskan putranya KiaiAbdul Hakam Mubarok dan dua pengasuh pesantren lainnya, yaituKiai Anwar Mu'rob dan Kiai Mufti Labib.

Seiring dengan kemajuan teknologi informasi, pengajaran kitab-kitab Islam klasik di Pesantren Karangasem tidak lagi dilakukan secara sorogan atau wetonan. Pada Agustus 2020, para pengurus pesantren menggagas televisi berbasiskan aplikasi YouTube dengan nama Al Manar TV. Pelibatan media sosial ini dimaksudkan agar pengkajian kitab-kitab Islam klasik, tafsir al-Qur'andan ceramah Islam bisa dinikmati seluruh santri, warga sekitar dan masyarakat luas.

Seluruh santri dituntut untuk mampu memahami kitab-kitab Islam klasik yang diajarkan di Pesantren Karangasem. Hal ini bertujuanagar menjadi bekal pengetahuan yangbisa diberikan kepada masyarakatsecara luas di masa mendatang.Dengan demikian, penguasaan kitab-kitab Islam klasik berkontribusi besar membentuk corak pemikiran keislaman yang kosmopolitan bagi seluruh stakeholder Pesantren Karangasem. Sementara bagi masyarakat sekitar, pengajian agama yang diadakan setelah sholat subuh dan disyiarkan melalui Al Manar TV dapat menjadi alternatif untuk mendapatkan rujukan pandangankeislaman yang moderat. Apalagi, kehidupan beragama masyarakat pesisir Lamongan sedang dihadapkan pada infiltrasi keagamaan yang diinisiasi oleh gerakangerakan Islam fundamentalis.

Pada umumnya, tradisi mempelajari kitab Islam klasik di pesantren sudah berlangsung sejak lama. Kitab-kitab tersebut diajarkan oleh seorang kiai dengan tidak sekedar dibaca dan diartikan dari teks Arab ke bahasa Indonesia atau Jawa. Tujuan kitabkitab Islam klasik tersebut mengajarkan para santri untuk memiliki sikap moderat, inklusif dan menghargai perbedaan pandangan. Seperti halnya dengan mempelajari kitab Bidayatul Mujtahidwa Nihayat al-Muqtasid, yang sengaja diajarkan agar para santri terbiasa menghadapi perbedaan pendapat danterbuka dengan pemikiran baru sekalipun yang dipertantangkan adalah permasalahan fikih.

Di sisi yang lain, Pesantren Karangasem juga menekankan berbagai kegiatan ekstrakurikuler yang menunjang kemampuan santri dalam berbahasa asing. Setiap pagi diadakan kursus bahasa Arab dan Inggris untuk seluruh santri dengan tingkatan kelas masing-masing.Kemudian, santri juga dilatih untuk bisa berpidato dalam dua bahasa tersebut melalui program Muhadlorah. Sementara itu, kegiatan ekstrakuler yang bertujuan memperkokoh komitmen santri terhadap kedaulatan negara,pembentukan karakter, dan pembinaan kepemimpinan dilakukan melalui Pramuka dan keterlibatan para santri di Ikatan Pelajar Muhammadiyah (IPM).

Dengan demikian, sangat layak apabila Pesantren Karangasem Muhamamdiyah Paciran disebut sebagai pondok yang terbuka, transparan, berkompeten dan dinamis terhadap perkembangan zaman. Integrasi pendidikan Islam dan umum yang diimplementasikan dalam sebuah kurikulum pesantren menjadi bukti bahwa pesantren ini kompeten dan mampu menjawab tantangan zaman. 
Nafik Muthohirin, dkk.: Resiliensi Pesantren Terhadap Ekstrimisme Kekerasan...

Berbagai program kegiatan pembelajaran dan aktivitas keislaman para santri di dalam Pesantren Karangasem tersebut penting untuk menciptakan resiliensi dari infiltrasi ideologi ekstrimisme kekerasan berbasiskan agama. Apalagi, sebagaimana dijelaskan di awal naskah ini, bahwa letak berdirinya Pesantren Karangasem di pesisir utara Lamongan merupakan kawasan yang rentan terpapar terlebih daerah ini pernah menjadi kantong pergerakan ISIS. Secara umum, model resiliensi yang dimiliki Pesantren Karangasem juga bisa membentengi warga sekitar dari idelogi ekstrimis. Pasalnya, lingkungan masyarakat pesisir Lamongan yang berwatak keras dan secara geografis padat penduduk dengan kultur keislaman yang kental menciptakan peluang bagi masuknya aktor-aktor Islam radikal.

\section{Filsafat Pendidikan Muhammadiyah}

"Dadijo kiai sing kemadjoean" memuat pesan mendalam yang mengharapkan agar pendidikan Muhammadiyah dapat melahirkan para generasi Islam yang berpikiran progresif, berintelektual tinggi, bersikap welas asih dan terbuka, serta berempati dan terlibat dalam penyelesaian berbagai masalah kemanusiaan. Dari sejumlah konsep kunci yang didasarkan kepada tiga dokumen resmi Muhammadiyah yang secara khusus mengkaji filsafat pendidikan Muhammadiyah (Mulkhan, Abdul Munir; Abrar, 2019), keseluruhannya menempatkan akal, ilmu pengetahuan, penguasaan teknologi, sikap keterbukaan, dan pembebasan manusia dari belenggu kemiskinan dan kebodohan. Ini semua merupakan pondasi filsafat Muhammadiyah yang perlu dikedepankan dalam praktik pendidikan Islam (Mulkhan, 1990).

Meski demikian, M. Amin Abdullah menjelaskan, sejumlah konsep kunci yang menjadi fondasi filsafat pendidikan Muhammadiyah memerlukan pembaruan (tajdid) (Abdullah, 2019). Globalisasi dan kemajuan teknologi informasi berkontribusi besar terhadap perubahan pemikiran dan pelembagaan pendidikan Islam di Indonesia. Berbagai situasi dunia yang baru seperti halnya kemunculan media sosial, populisme Islam, pergeseran sosial politik, politik identitas dan ancaman gerakan ekstrimisme kekerasan berbasiskan agama, menjadi tantangan baru yang memerlukan adaptasi ulang bagi konsep pendidikan Islam di Muhamamdiyah.

Dalam kaitannya dengan infiltrasi pandangan keislaman yang keras dan tertutup, filsafat pendidikan Muhammadiyah tersebut bisa menjadi fondasi dan modal penting bagi penciptaan resiliensi dari aktor-aktor kelompok ekstrimisme kekerasan berbasiskan agama yang ingin masuk ke dalam sistem atau lembaga pendidikan yang dikelola Muhammadiyah. Seperti halnya yang terdapat di Pesantren Karangasem Muhammadiyah Lamongan, kurikulum pendidikan Islam yang terpadu dengan kurikulum nasional, menjalin kerjasama pendidikan dengan berbagai universitas besar dari banyak negara maju, serta penguatan pemahaman nasionalisme dan pluralisme menjadi sejumlah program penting yang memengaruhi kekuatan resiliensi pesantren dari ancaman gerakan dan pemikiran ekstrimisme kekerasan berbasiskan agama.

\section{Kiai Sebagai Agen Kunci Moderasi}

Kawasan pesisir utara Jawa Timur merupakan daerah yang paradoks. Pada satu sisi dikenal sebagai daerah santri, tapi pada sisi yang lain menjadi kantong pergerakan bagi organisasi bercirikan ekstrimisme keagamaan. Disebut sebagai masyarakat dengan kultur santri karena berdiri banyak pesantren dengan kepemimpinan para kiai yang karismatik. Di era pra kemerdekaan, terdapat sejumlah kiai populer seperti Kiai Abdurrahman Syamsuri (Pesantren Karangasem), Kiai Abdul Ghofur dan Kiai Mustofa Karim (Pesantren Kranji), dan Kiai Amin (Pesantren Al-Amin Tunggul). Para kiai ini memiliki kewibawaan yang kuat di tengah masyarakat sekitar karena berpengetahuan luas dalam ilmu-ilmu keislaman. Mereka menjadi ulama di tengah masyarakat dan menjadi pemimpin di medan 
perang. Salah satu kiai karismatik yang gugur melawan Belanda adalah Kiai Amin, putra Kiai Mustofa yang memimpin Pesantren Al-Amin Tunggul.

Salah satu kiai karismatik yang meninggalkan warisan besar tradisi intelektualisme Islam pesantren adalah Kiai Abdurrahman Syamsuri. Dialahir pada 1 Oktober 1925, bapaknya Kiai Syamsuri dan kakeknya Kiai Idris adalah dua kiai terpandang di Lamongan. Kiai Abdurrahman sudah diajarkan ilmu-ilmu agama oleh bapak dan kakeknya sejak kecil. Keduanya menjadi figur teladan yang menginspirasi Kiai Abdurrahman untuk menjadi mubaligh, guru, kiai, sekaligus aktivis organisasi. Dia tipikal anak yang santun, tekun dan cerdas. Karena kecepatannya menguasai ilmu-ilmu agama, bapaknya mengirim Abdurrahman kecil ke Kiai Fattah di Tulungagung untuk menghafal dan mempelajari ilmu al-Qur'an. Abdurrahman telah menamatkan hafalan al-Qur'an sebanyak 30 juz di usia 15 tahun.

Kiai Abdurrahman adalah agen kunci terbentuknya resiliensi dari ideologi ekstrimisme kekerasan berbasiskan agama di tubuh Pesantren Karangasem Muhammadiyah Paciran Lamongan. Dia dikenal masyarakat sebagai ulama yang berkarismakarena hidupnya yang sederhana dan memiliki kedalaman intelektual di bidang ilmu-ilmu keislaman. Meski berasal dari keluarga kiai terpandang, Kiai Abdurrahman menjalani hidup sederhana. Suami Nyai Walidjah tersebut bertani dan tukang gergaji kayu dan batu kapur pada pagi hingga sore hari, dan mengisi ceramah, mengajar mengaji dan menghafal al-Qur'an pada malam hari.

Kiai Abdurrahman dikenal sebagai mubaligh yang santun, toleran, welas asih, memiliki pergaulan luas, dan berpikiran terbuka. Dia bisa menjalin persahabatan dengan berbagai tokoh pergerakan dan ulama dari berbagai organisasi yang berbeda ideologi. Tidak mengherankan bila pergumulan Abdurrahman Syamsuri dengan para pemimpin organisasi Islam, seperti M. Nastir, H. Misbach, dan para kiai pesantren di Jawa Timur membuatnya dikagumi banyak orang.

Dalam hal kepemimpinan, dia pernah menjadi anggota DPRD Lamongan dari Partai Masyumi (1958). Dia juga tercatat pernah aktif di organisasi kepemudaan Islam, Gerakan Pemuda Anshor (GP Anshor) dan Gerakan Pemuda Islam Indonesia (GPII); serta kepemimpinannya di organisasi kemasyarakatan Islam, Direktur PGA Muhammadiyah Paciran (1957), Ketua Majelis Pendidikan dan Pengajaran Pimpinan Cabang Muhammadiyah Blimbing (1960), Ketua Pimpinan Cabang Muhammadiyah Paciran (1967), Ketua Pimpinan Daerah Muhammadiyah Lamongan (1977-1992), Majelis Tarjih dan Tanwir Pimpinan Pusat Muhammadiyah (1978-1992), Ketua Bagian Pendidikan Ittihad al'Ma'ahid al-Islamiyah (1968) dan anggota Majelis Ulama Indonesia Daerah Tingkat I Jawa Timur (1971) (Islami et al., 2011).

Kiai Abdurrahman tidak hanya seorang Kiai Kampung yang memimpin sebuah pesantren, tetapi juga seorang aktivis pergerakan Islam, mubaligh, politisi, guru, sekaligus hakim pengadilan yang mengurusi perceraian. Dia juga seorang hafidz (penghafal alQur'an) yang mengerti ilmu nahwu, sharaf, tafsir al-jalalain, musthalahul hadist, fikih, faraidh dan berbagai ilmu keislaman lainnya.

Latarbelakang pendidikan Kiai Abdurrahman ditempuh dari sejumlah pesantren bercorak Salafiyah di Jawa Timur, seperti Pesantren Kranji, Pesantren Mangunsari Tulungagung, Pesantren Tebuireng Jombang, dan Pesantren Kedunglo Bandar Kidul Kediri. Sebab itu, tidak mengherankan bila karisma Kiai Abdurrahman sukses memikat para remaja dari banyak desa di pesisir Lamongan untuk belajar di Pesantren Karangasem sejak awal berdiri. Kiai Abdurrahman mengajarkan berbagai kitab Islam karya ulama klasik kepada mereka. Ketika mengajarkan kitab-kitab Islam klasik itu, dia menggunakan metode sorogan khas model pembelajaran Islam di pesantren tradisional. Beberapa kitab Islam 
Nafik Muthohirin, dkk.: Resiliensi Pesantren Terhadap Ekstrimisme Kekerasan ...

klasik yang diajarkannya adalah Fathul Mu'in, Kitab Taqrib, Rahmatul Ummah, Tafsir Jalalain, dan Kifayatul Akhyar (Islami et al., 2011).

Kiai Abdurrahman juga mengajarkan tajwid dan tartil al-Qur'an, ilmu nahwu dan sharaf, tafsir, ilmu al-Qur'an dan ilmu al-Hadist. Pada konteks inilah, dapat dipahami bahwa Kiai Abdurrahman mengorientasikan Pesantren Karangasem sebagai pondok sekaligus madrasah yang menjadi tempat tinggal dan rumah belajar bersama (Islami et al., 2011). Dia juga menjadi rujukan masyarakat sekitar dalam berbagai penyelesaian urusan agama dan sosial, seperti pembagian harta waris, pemberian nama anak, urusan perkawinan,perceraian dan lain sebagainya.

Penguasaan terhadap berbagai kitab Islam klasik sekaligus penganjur agama, dan aktivis sosial yang kompeten menjadi pengakuan otentik dari masyarakat Lamongan terhadap Kiai Abdurrahman sebagai kiai berkarisma. Zamakhsyari Dhofier melihat bahwa semakin sulit kitab-kitab Islam klasik yang diajarkan, maka seorang kiai akan semakin dikagumi masyarakat (Dhofier, 1980). Kepemilikan karisma pada diri kiai pesantren secara umum, termasuk Pesantren Karangasem yang telah memiliki ribuan santri sejak 1980-an, merupakan pengejewantahan atas doktrin Islam yang mengatur supaya setiap manusia menjalin relasi antar sesama dan juga kepada Tuhan-Nya. Pada konteks ini, ajaran Islam memberikan keluasan bagi figur kiai untuk merajut ikatan yang sangat kuat dengan masyarakat (Dhofier, 1980).

Kewibawaan Kiai Abdurrahman sangat kuat memengaruhi madzab keagamaan Pesantren Karangasem. Hal ini juga berpengaruh besar terhadap corak pandangan keislaman masyarakat Lamongan. Pada masa berdiri tahun 1948 hingga 1957, paham keislaman pesantren awalnya mengikuti madzab Salafiyah Syafi'iyah. Namun berganti menjadi Wahabiyah di akhir 1950-an seiring dengan keterlibatannya di Masyumi dan Muhammadiyah (Islami et al., 2011). Perubahan tersebut berdampak pada aspek kelembagaan dan pendidikan. Secara kelembagaan, pesantren yang awalnya bernama alMa'had al-Islamy Karangasem berganti menjadi Pondok Pesantren Karangasem Muhamamadiyah. Kemudian, aktifitas tahlil, dziba'an dan mengaji Kitab Taqrib, Fathul Mu'in dan Rohmatul Ummah yang awalnya menjadi rutinitas kegiatan keislaman para santri diganti mengaji kitab Bidayatul Mujtahid, Fikih Sunnah Imam Arba'ah, Bulughul Maram, Riyadus Sholihin, Sahih Muslim, dan Tafsir Jalalain yang semua kitab ini umum diajarkan di pesantren Wahabiyah.

Nama Pesantren Karangasem Muhammadiyah Lamongan bertahan sampai sekarang, dipimpin olehputra Kiai Abdurrahman, yaitu Kiai Abdul Hakam Mubarok dan sejumlah pengasuh lainnya. Kiai Abdul Hakam Mubarok menyebut bapaknya tersebut sebagai ulama berakhlak al-Qur'an (Faris Ma'ani, Bambang Siswoyo, 2012). Keteladanan dan kewibawaan Kiai Abdurrahman dilanjutkan Kiai Mubarok dan sejumlah pengasuh pesantren seperti Kiai Anwar Mu'rob dan Kiai Mufti Labib. Mereka mewarisi keilmuan Islam Kiai Abdurrahman, dan mengajarkannya kepada para santri dan warga lokal. Berbagai kajian keislaman tetap diadakan seperti Tafsir Hadist, Tafsir al-Qur'an dan berbagai kitab Islam karya ulama Islam klasik.

Kepribadian Kiai Abdurrahman dan sejumlah pengasuh pesantren sesudahnya mencerminkan watak pesantren yang teduh. Karisma para kiai inidibangun berdasarkan otentisitas keilmuan Islam yang didapat dari para gurunya yang juga sebagai kiai pesantren besar di Jawa atau belajar dari ulama di Makkah atau Madinah. Para kiai pesantren tidak hanya membacakan dan menerjemahkan ke dalam bahasa Jawa ketika mengajar kitabkitab Islam klasik. Mereka memberikan berbagai pendapatnya pribadi atas keluasan ilmu keislaman yang dimilikinya (Dhofier, 1980).

Melalui berbagai pendapatnya pribadi, para kiai pesantren menjelaskan setiap teks dari kitab-kitab klasik tersebut dengan pemaknaan dan pembacaan yang sesuai realitas 
perilaku keagamaan masyarakat kontemporer. Pada aspek ini, relevan sebagaimana yang dijelaskan Irfan Abubakar dan Idris Hemay bahwa resiliensi pesantren dari ancaman ideologi Islam radikal dapat tumbuh dari model pengajaran kitab-kitab Islam klasik dan kohesi sosial seorang kiai yang karismatik (Abubakar \& Hemay, 2020).

\section{KESIMPULAN}

Pesantren memiliki peran penting dalam membentuk perilaku sosial dan keberagamaan masyarakat Muslim di Indonesia. Salah satu alasannya karena kiai menjadi referensi masyarakat dalam berperilaku dan menentukan pemikiran sesuai ajaran Islam. Dalam rentang sejarah yang panjang, kiai menjadi role model dalam pembentukan moral, karakter, dan corak keberagamaan santri dan masyarakat (Ihsan dan Umar, 2020). Atas kepercayaan yang begitu kuat itulah kiai menempati posisi elit dalam strata sosial di negeri ini. Tidak hanya dalam berbagai urusan agama, pilihan politik kiai sangat menentukan kesadaran berpolitik warga di masa sekarang.

Pesantren telah memiliki corak pendidikan Islam tersendiri jauh sebelum Indonesia terbebas dari penjajahan. Betapapun model pengajaran itu dinilai klasik dan tradisional, tetapi sistem pendidikan Islam pesantren terbukti mampu mencetak para pemimpin masa depan yang gemilang. Tidak hanya menjadi penganjur agama, pada kenyataannya tradisi intelektual pesantren banyak melahirkan pemimpin perjuangan, tokoh politik, guru, wartawan, sampai aktivis kemanusiaan. Di era sekarang, lulusan pesantren bisa berprofesi apapun dengan modal keilmuan Islam sebagai kompetensi tambahan.

Persoalannya, terdapat sejumlah pesantren yang ditengarai menjadi kantong pergerakan kelompok Islam ekstrimis selama dua dekade terakhir. Pihak kepolisian menyebut beberapa pesantren tersebut berafiliasi dengan jaringan kelompok teroris Jamaah Islamiyah (JI), dan keberadaannya terletak di Jawa dan luar Jawa. Fakta ini mengejutkan banyak pihak karena selama ini pesantren dikenal sebagai lembaga pendidikan Islam yang mengajarkan nilai moral, karakter, dan kemanusiaan.

Pesantren bukanlah satu-satunya lembaga pendidikan di Indonesia yang terpapar ide-ide ekstrimisme kekerasan berbasiskan agama. Infiltrasi sejumlah gerakan fundamentalisme Islam juga menyasar ke berbagai perguruan tinggi negeri. Meski tidak dapat dikatakan radikal secara tindakan, namun ide penolakan terhadap demokrasi, Pancasila, nasionalisme dan berbagai pokok pikiran negara modern merupakan tahap awal dari aksi ekstrimisme kekerasan yang lebih nyata (Muthohirin, 2014). Dalam satu dekade terakhir, berbagai kelompok Islam radikal juga melakukan transformasi strategi gerakan dengan menyasar kaum muda di media sosial. Mereka menjadikan jejaring sosial sebagai media untuk melakukan perekrutan, propaganda dan diseminasi pandangan keagamaan yang ekstrimis (Muthohirin, 2015).

Infiltrasi kelompok Islam radikal tersebut menjadi fenomena yang terjadi di Indonesia pasca Reformasi (1998). Bahkan, pedesaan yang jauh dari keramaian kota seperti Lamongan menjadi kantong pergerakan teroris. Beberapa kelompok yang diidentifikasi sebagai organisasi Islam fundamentalis seperti Jamaah Salafi, Tarbiyah dan HTI juga tumbuh di daerah tersebut. 
Nafik Muthohirin, dkk.: Resiliensi Pesantren Terhadap Ekstrimisme Kekerasan...

Selama ini pesisir Lamongan dikenal sebagai basis tradisi Islam santri karena banyak berdiri pesantren dengan kepemimpinan kiai yang berkarisma, baik yang terafiliasi dengan Muhammadiyah maupun NU (Anshori, 2020). Berbagai pesantren tersebut sekaligus menjadi tempat kaderasisasi ulama dan aktivis dari kedua organisasi Islam tersebut. Secara umum, relasi sosial dan tradisi masyarakat di pesisir Lamongan juga dibangun berlandaskan kepercayaan terhadap tokoh-tokoh agama dari Muhammadiyah dan NU. Akan tetapi, bangunan kepercayaan terhadap ulama atau intelektual dari kedua organisasi keagamaan tersebut mengalami fragmentasi seiring dengan kemunculan mubaligh-mubaligh dari aktivis FPI, JAD, HTI, Salafi dan HTI.

Sebab itu, sangat penting menjaga ketahanan penduduk setempat dari masuknya ide dan gerakan kelompok ekstrimisme kekerasan berbasiskan agama. Strategi yang paling mungkin dilakukan adalah dengan memaksimalkan model resiliensi yang bersumber dari Pesantren Karangasem Muhammadiyah Paciran. Pesantren yang didirikan oleh Kiai Abdurrahman Syamsuri tersebut menjadi satu dari banyak pesantren yang berdiri sebagai kearifan lokal masyarakat pesisir Lamongan.

Bentuk resiliensi Pesantren Karangasem di antaranya bersumber dari karisma para kiai yang memimpin pesantren. Kewibawaan tersebut didapat atas keabsahan mereka sebagai ulama yang menguasai ilmu-ilmu keislaman, hafal al-Qur'an, guru dan penganjur agama, serta pemimpin dan aktivis organisasi keagamaan. Berbagai pendapatnya merupakan analisis yang didasarkan pada pengkajiannya terhadap kitabkitab Islam otoritatif yang ditulis para ulama klasik. Sehingga, karisma tersebut tersemat secara tidak langsung dari para santri dan masyarakat sekitar, yang menjadikannya sebagai panutan dalam berprilaku sesuai ajaran Islam.

Model resiliensi terhadap gerakan ekstrimisme kekerasan berbasiskan agama juga bisa didapatkan dalam bentuk praktik pendidikan Islam yang telah berjalan di Pesantren Karangasem. Model pendidikan di pesantren ini mengikuti kurikulum nasional, dengan mengintegrasikannya pada berbagai materi keislaman. Salah satu contohnya adalah para santri didorong untuk mempelajari ilmu-ilmu al-Qur'an, hafalan al-Qur'an dan al-Hadist sekaligus diajarkan menguasai Bahasa Arab dan Inggris. Untuk menumbuhkan rasa nasionalisme, para santri difasilitasi beberapa kegiatan ekstrakurikuler seperti mengikuti IPM dan Pramuka. Kemudian, pembelajaran kitab-kitab Islam klasik mendidik para santri untuk menghargai guru atau orang yang lebih tua, terbuka terhadap perbedaan pandangan (keagamaan), toleran, keadilan, perdamaian, dan memiliki empati kemanusiaan.

Berbagai bentuk resiliensi Pesantren Karangasem tersebut memiliki implikasi yang serius dalam membentuk corak keberagamaan masyarakat pesisir Lamongan yang moderat dan kosmopolitan. Hal ini disebabkan oleh dua hal, yaitu: pertama, figur kiai pesantren yang karismatik berpengaruh menginspirasi penduduk lokal untuk berperilaku agama seperti yang dicerminkan kiai panutannya; kedua, Pesantren Karangasem memiliki ratusan alumni yang menjadi mubalig dan guru agama yang tersebar di sejumlah daerah di pesisir Jawa seperti Babat, Gresik, Bojonegoro, Surabaya, Tuban, Pati, Rembang dan lainnya. Para alumni ini menjadi agen penting dalam penyebaran watak Islam moderat. Mereka dapat disebut sebagai kiai kampung yang menjadi panutan dan memiliki pengaruh kepemimpinan di tingkat lokal, sehingga 
peran mereka di tengah masyarakat bisa menjadi resiliensi terhadap infiltrasi gerakan aktor-aktor Islam radikal.

Penting untuk dipahami bersama bahwa terlepas dari maraknya berbagai aksi kekerasan agama yang terjadi baik di masa lalu maupun saat ini, doktrin agama tidak pernah mengajarkan dan membenarkan tindakan kekerasan. Pesantren merupakan simbol perdamaian Islam. Beragam kultur dan identitas santri yang berasal dari bermacam daerah selalu terajut secara damai karena pemahaman Islam yang inklusif dan keteladanan dari para kiai yang karismatik.

Dinamika pesantren yang mengalami tantangan serius akibat masifnya gerakan ekstrimisme kekerasan berbasiskan agama di masa sekarang, maka diperlukan beberapa langkah strategis yang berdampak secara luas. Pertama, kebijakan makro nasional, regional dan global yang berorientasi pada rekonstruksi instrumen hukum yang adil, fair dan transparan atas tindakan kekerasan, khususnya yang menyangkut masifitas gerakan kelompok Islam radikal. Tekanan global atas gerakan kekerasan yang dilakukan kelompok tertentu hendaknya tidak menyudutkan umat Islam secara luas. Pekerjaan ini membutuhkan upaya kerjasama secara langsung antara berbagai pihak, baik pesantren, pemerintah, maupun sejumlah lembaga internasional yang memiliki perhatian pada persoalan ini. Kedua, perlunya pendidikan alternatif agar semakin terakomodasinya pendidikan yang berorientasikan pada pengembangan nilai-nilai pluralitas. Ketiga, penguatan terhadap kualitas kurikulum dan sistim pendidikan sangat dibutuhkan oleh pesantren, yang dalam jangka panjang akan meredam pengaruh negatif bangkitnya gerakan-gerakan militan Islam.

Sebagai sebuah organisasi Islam modern, Muhammadiyah berdiri dengan salah satu tujuannya yaitu memoderasi umat Islam dari eksklusivisme. Begitupun, dengan yang dicontohkan melalui salah satu pesantrennya di Jawa Timur, yaitu Pondok Pesantren Karangasem Muhammadiyah Lamongan. Pesantren ini berkontribusi besar terhadap diseminasi paham dan perilaku keagamaan masyarakat di pesisir utara Jawa Timur, terutama melalui karisma para kiai dan alumninya yang bekerja memoderasi keberagamaan masyarakat.

\section{DAFTAR PUSTAKA}

Abdullah, M. A. (2019). Fresh Ijtihad: Manhaj Pemikiran Keislaman Muhammadiyah di Era Disrupsi. Suara Muhammadiyah.

Abubakar, I., \& Hemay, I. (2020). Pesantren Resilience: The Path to Prevent Radicalism and Violent Extremism. Studia Islamika, A27(2), 397-404.

https://doi.org/10.36712/sdi.v27i2.16766

Anshori, I. (2020). Dinamika Pesantren.

Bachtiar, H. (2020). Ijtihad Kontemporer Muhammadiyah Dar al-'Ahdi wa al-Syahadah: Elaborasi Siyar dan Pacasila. Suara Muhammadiyah.

Chirzin, M. H. (1995). Agama dan Ilmu dalam Pesantren. In Pesantren dan Pembaharuan (p. 88). LP3ES.

Dhofier, Z. (1980). Use of theses. 2, i-335.

Faris Ma'ani, Bambang Siswoyo, dan H. A. H. (2012). Sekokoh Karang, Seteduh Pohon Asem: Biografi KH. Abdurrahman Syamsuri. Karangasem Media.

Farish A. Noor, Yoginder Sikand, dan M. van B. (ed. . (2008). Behind the Wall: Re- 
Nafik Muthohirin, dkk.: Resiliensi Pesantren Terhadap Ekstrimisme Kekerasan...

Appraising the Role and Importance of Madrasas in The World Today. In The Madrasa in Asia: Political Activism and Transnational Linkage (pp. 9-21). Amsterdam University Press.

Ihsan dan Umar, A. (2020). Kyai as Al-Qudwah Al-Khasanah: The Role of Kyai in Shaping Religious Culture in Islamic Education Institution. Al-A'raf: Jurnal Pemikiran Islam Dan Filsafat, XVII(2), 329-345.

Indonesia's Lamongan Network: How East Java, Poso, and Syria are Linked, (2015).

Islami, R., Sejarah, D. I., Budaya, F. I., \& Airlangga, U. (2011). SKRIPSI GELIAT PERGURUAN MUHAMMADIYAH : PESANTREN KARANGASEM PACIRAN LAMONGAN GELIAT PERGURUAN MUHAMMADIYAH : PESANTREN KARANGASEM PACIRAN LAMONGAN.

Lewis, B. (2002). What Went Wrong: The Clash Between Islam and Modernity in the Middle East. Weidenfeld \& Nicolson.

Marzuki, Miftahuddin, \& Murdiono, M. (2020). Multicultural education in salaf pesantren and prevention of religious radicalism in Indonesia. Cakrawala Pendidikan, 39(1), 12 25. https://doi.org/10.21831/cp.v39i1.22900

Mulkhan, Abdul Munir; Abrar, R. H. (2019). Jejak-jejak Filsafat Pendidikan Muhammadiyah: Membangun Basis Etis Filosofis bagi Muhammadiyah. Suara Muhammadiyah.

Mulkhan, A. M. (1990). Pemikiran K.H. Ahmad Dahlan dan Muhammadiyah dalam Perspektif Perubahan Sosial. Bumi Aksara.

Muthohirin, N. (2014). Fundamentalisme Islam: Gerakan dan Tipologi Pemikiran Aktivis Dakwah Kampus. IndoStrategi.

Muthohirin, N. (2015). Radikalisme Islam dan Pergerakannya di Media Sosial. Afkaruna: Indonesian Interdiciplinary Journal of Islamic Studies., 11(2), 240-259.

Rosyidi, S. (1975). Perkembangan Filsafat Pendidikan dalam Muhammadiyah. PWM Dikdasmen Jawa Tengah.

Syam, N. (2003). Tradisi Islam Lokal Pesisiran : Studi Konstruksi Sosial Upacara Pada Masyarakat Pesisir Palang Tuban , Jawa Timur.

Tibi, B. (1998). The Challenge of Fundamentalism: Political Islam and the New World Disorder. Universty of California Press.

Woodward, K. (2015). Indonesian Schools: Shaping the Future of Islam and Democracy in a Democratic Muslim Country. Journal of International Education and Leadership, 5(1). 